\title{
Sør-Trøndelag Aktivitets-Relaterte Tiltak (START) - Samhandling for bedre helse
}

\section{Et pilotprosjekt for nasjonal sykdomsforebygging gjennom økt fysisk aktivitet}

\author{
Tommy Aune Rehn ${ }^{1}$, Øivind Rognmo ${ }^{1}$, Jan Erik Ingebrigtsen ${ }^{2}$, John Tore Vik ${ }^{3}$ \\ og Ulrik Wisløff ${ }^{1}$ \\ 1) K. G. Jebsen Center for Exercise in Medicine, Institutt for sirkulasjon og bildediagnostikk, NTNU, Trondheim \\ 2) Senter for Idrettsforskning, NTNU Samfunnsforskning AS, Trondheim \\ 3) Enhet for regional utvikling, Sør-Trøndelag Fylkeskommune
}

Korrespondanse: Tommy Aune Rehn, tommyrehn@yahoo.no

\begin{abstract}
SAMMENDRAG
Høy forekomst av kroniske sykdommer og stigende helseutgifter representerer i lys av den kommende eldrebølgen en stor samfunnsøkonomisk utfordring. Den negative helseutviklingen er i ferd med å bli et nasjonalt problem og må få konsekvenser for fremtidig norsk helsepolitikk. Fysisk inaktivitet er en livsstilsfaktor som er sterkt assosiert med lavt nivå av kondisjon, total dødelighet og død av hjerte- og karsykdom. Studier viser at selv en liten bedring i kondisjon forventes å gi betydelig økt forventet levealder og at individer som har et bra kondisjonsnivå har opptil 15 flere leveår med god helse hvor de er selvhjulpne. Økt fysisk aktivitet har en gunstig effekt på alle risikofaktorer for kronisk sykdom og tidlig død, og vi mener derfor at man bør legge til rette for å øke det generelle fysiske aktivitetsnivået i befolkningen og bedre kunnskapen om fysisk aktivitet. Økt fysisk aktivitet vil forventes å bedre folkehelsen ved å redusere sykdomsforekomst, medisinbruk og dødelighet samt øke arbeidsevnen i populasjonen, noe som igjen vil redusere de samfunnsøkonomiske utgiftene. For å lykkes med dette, har vi tatt initiativ til prosjektet "Sør-Trøndelag Aktivitets-Relaterte Tiltak" (START), som er tenkt å være en koordinert populasjonsbasert samhandling for bedre helse gjennom økt fysisk aktivitet rettet mot alle lag i befolkningen, fra krybbe til grav. Målet er at START skal danne grunnlag for nasjonal implementering av tiltak slik at vi oppnår en helsepolitisk bærekraftig utvikling i årene som kommer. Denne artikkelen beskriver START og bakgrunnen for prosjektet.
\end{abstract}

\section{Rehn TA, Rognmo Ø, Ingebrigtsen JE, Vik JT, Wisløff U. Sør-Trøndelag Activity-Related Trial (START) -} Cooperation for better health. Nor J Epidemiol 2011; 20 (2): 209-216.

\section{ENGLISH SUMMARY}

High incidence of chronic diseases and rising health expenditure represents in light of the increasing proportion of elderly in our society a development that cannot be considered sustainable in the long run. The negative health trend is becoming a national problem and should have consequences for future Norwegian health policy. Physical inactivity is among the lifestyle factors most strongly associated with a low level of exercise capacity, all-cause mortality and death from cardiovascular disease. Studies show that even a small improvement in exercise capacity offers significantly increased life expectancy and that individuals who have a good fitness level have up to 15 more years of life with good health where they are self-reliant. Increased physical activity has a beneficial effect on all risk factors for chronic disease and premature death. We believe that the overall physical activity levels in the population needs to be increased and knowledge about physical activity should be improved. Increased physical activity will improve public health by reducing disease incidence, medical use and mortality as well as increasing working capacity in the population, which in turn will reduce the socioeconomic costs. To succeed with this, we have initiated the project "Sør-Trøndelag Activity-Related Trial (START), which is a coordinated population-based interaction for improved health through increased physical activity aimed at all strata of the population, from cradle to grave. The intention is that START will form the basis for national implementation of measures to ensure that we achieve a sustainable development in health policy in the years to come. This article describes START and the background for the project.

\section{INNLEDNING}

Vi vet at fysisk aktivitet er et effektivt tiltak mot en rekke sykdommer og lidelser i tillegg til for tidlig død. Samtidig er det en av de mest tilgjengelige og billigste metodene for å bedre den kollektive helsa i et samfunn og for den enkelte. Allikevel ser man at det generelt er et lavt aktivitetsnivå i befolkningen, samtidig som de offentlige tiltakene er spredt og ofte uten den politiske satsingen som skal til for en tung og bred implementering. Torontocharteret som ble utformet under en konferanse i 2002 [6] understreker betydningen av fysisk 
aktivitet for helse, livskvalitet og samfunnsøkonomi og er et globalt opprop der man etterlyser politisk satsing rettet mot helsefremmende fysisk aktivitet $\mathrm{i}$ det brede lag av befolkningen.

Samhandlingsreformen som ble vedtatt i april 2010 (St.meld. nr. 47) [21] påpeker at hovedutfordringen for folkehelsa er knyttet til den demografiske utviklingen vi står overfor, med økende andel eldre, tiltagende helserelaterte utgifter og en endring i sykdomsbildet. Dette representerer en reell trussel mot samfunnets økonomiske bæreevne. Videre presiseres behovet for primærforebygging og tidlig intervensjon for å redusere forekomsten av kroniske sykdommer. Ved å samle den teoretiske og praktiske kunnskapen om fysisk aktivitet både på samfunns- og individnivå, samt etablere en akademisk, politisk og privat dugnadsånd for å heve aktivitetsnivået $\mathrm{i}$ befolkningen tror vi at man kan bedre folkehelsa og samtidig påvise en samfunnsøkonomisk gevinst. Dette vil kreve dyptgripende, langsiktige, men ikke minst gjennomførbare tiltak i alle aldersgrupper, fra krybbe til grav, der en i størst mulig grad utnytter allerede eksisterende samfunnsstrukturer. Gjennom Sør-Trøndelag Aktivitets-Relaterte Tiltak (START) ønsker vi å vise at det er mulig å bedre folkehelsen $\mathrm{i}$ Sør-Trøndelag gjennom økt fysisk aktivitet. Vi ønsker å synliggjøre hvilke tiltak som er virkningsfulle slik at dette på sikt kan implementeres på nasjonalt nivå. Også $\mathrm{i}$ et internasjonalt perspektiv vil en slik studie være svært nyttig da dette er et globalt problem. Data fra Helseundersøkelsen i Nord-Trøndelag (HUNT) og våre nasjonale sykdomsregistre gir oss en unik og forpliktende mulighet til å vurdere effekten av de tiltak som iverksettes gjennom START-prosjektet, som vil være den mest omfattende populasjonsbaserte studien rettet mot fysisk aktivitet til nå.

\section{BAKGRUNN}

Kronisk sykdom er i følge Verdens Helseorganisasjon (WHO) den viktigste årsaken til død og uførhet på verdensbasis, og de fire ledende kroniske sykdommene hjerte/karsykdom, kreft, kronisk obstruktiv lungesykdom (KOLS) og type 2 diabetes - har felles biologiske risikofaktorer. Disse risikofaktorene inkluderer høyt blodtrykk, høyt blodsukkernivå, høyt kolesterolnivå og overvekt, som igjen kan relateres til usunt kosthold, fysisk inaktivitet og tobakksbruk [60]. WHO's helserapport fra 2002 slår fast at dødelighet, sykelighet og uførhet knyttet til disse fire sykdomsgruppene utgjør nesten $60 \%$ av alle dødsfall og $43 \%$ av den totale globale sykdomsbyrden. Innen 2020 vil dette bidraget forventes å øke til å omfatte $73 \%$ av alle dødsfall og $60 \%$ av den globale sykdomsbyrden [60]. De totale helseutgiftene i Norge per innbygger har doblet seg fra 1998 til 2008 [22]. Med en forventet kraftig økning i andelen eldre i befolkningen er det helt nødvendig å snu denne tendensen, da vi vet at omfanget av livsstilssykdommer øker, og blir mer behandlingskrevende, med økende alder. Det er i Norge i dag ca 600000 eldre over 67 år. Moderate anslag tilsier at dette tallet vil øke til 800000 i 2020 og til 1200000 i 2050 [22]. Det haster derfor med å iverksette varige forebyggende tiltak.

\section{OVERVEKT OG DIABETES}

I hele den vestlige verden rapporteres det om en epidemi av overvekt. Ferske tall fra HUNT viser at $60 \%$ av befolkningen kan klassifiseres som overvektige (body mass index $(\mathrm{BMI})>25)$ og av disse kan 1 av tre klassifiseres som fete (BMI > 30). Andelen overvektige menn er tredoblet de siste 20 år (www.hunt3.no) og forekomsten av diabetes har følgelig økt i Norge de siste tiårene. I 2004 ble diabetesforekomsten i Norge estimert ut i fra flere befolkningsbaserte undersøkelser og man fant at mellom 90000 og 120000 nordmenn led av denne sykdommen. Man anslo da at like mange har en udiagnostisert diabetes type II [52]. Tall fra reseptregisteret viser at bruk av diabeteslegemidler $\mathrm{i}$ 2007 tilsvarte en kostnad på 441 millioner kroner (www.reseptregisteret.no). Upubliserte data fra den siste HUNT-undersøkelsen (HUNT III) tyder på at forekomsten av diabetes type II fremdeles er økende, spesielt for menn. På sikt vil dette sannsynligvis resultere $\mathrm{i}$ en økning av diabetesrelaterte komplikasjoner som hjerte- og nyresykdom. Omfattende studier har vist at både vektreduksjon og fysisk aktivitet kan redusere utvikling og forekomst av diabetes type II $[2,3,29]$ og at dette kan være mer effektivt enn medikamentell behandling [28].

\section{INAKTIVITET}

Tall fra 2009 viser at $83 \%$ av norske 9-åringer tilfredsstiller de nasjonale anbefalingene om daglig fysisk aktivitet. Denne andelen faller imidlertid til $52 \%$ ved 15 års alder [22]. Norske gutte i ungdomsskole og videregående skole rapporterer 37-43 timer stillesittende aktivitet foran PC eller TV per uke i 2005, hvilket representerer en dobling fra 1997. For jenter i samme alder er tallet 30 timer i uken, også dette en dobling fra 1997 [57]. Generelt er det kun ca 20\% av den norske voksenbefolkningen (noe varierende etter kjønn og alder) som tilfredsstiller dagens anbefalinger om fysisk aktivitet [22]. Fysisk inaktivitet er isolert sett en risikofaktor for livsstilssykdommer som er jevnstor med høyt blodtrykk, ugunstig kolesterolnivå og røyking [38]. Økt fysisk aktivitet kan faktisk redusere mortaliteten tilsvarende røykeslutt [7]. På tross av dette potensialet er fokuset $\mathrm{i}$ forebyggende arbeid fortsatt $\mathrm{i}$ stor grad rettet mot effektiv medisinering. Nylige rapporter fra England og USA indikerer at fysisk inaktivitet er den hyppigste risikofaktoren for kronisk sykdom da hele $95 \%$ av den voksne populasjonen ikke etterlever anbefalingene om fysisk aktivitet [53,55]. I England har man videre estimert at kostnadene knyttet til fysisk inaktivitet er fem ganger høyere enn kostnaden relatert til røyking [43]. På bakgrunn av den betydningen inak- 
Tabell 1. Populasjonsbaserte intervensjonsstudier og deres effekt på sentrale folkehelseparametere og risikofaktorer.

\begin{tabular}{lll}
\hline Parameter & Påvist effekt & Ingen effekt \\
\hline $\begin{array}{l}\text { Dødelighet } \\
\text { Estimert risiko for }\end{array}$ & {$[46][48][59][9]$} & {$[31][13][37]$} \\
kardiovaskulær sykdom & {$[46][14][48][33][26][9]$} & {$[13][31][8][37]$} \\
$\begin{array}{l}\text { Type II Diabetes } \\
\text { Hypertensjon }\end{array}$ & {$[10]$} & {$[37]$} \\
& {$[47][14][1][48][13][59][37][23][10][32][35]$} & {$[19][30][8][33]$} \\
Hyperkolesterolemi & {$[26][9][24][51]$} & \\
Røyking & {$[47][14][48][59][23][10][33][35][26][24][51]$} & {$[19][1][30][8][13][37][32]$} \\
Kroppsmasseindeks & {$[47][19][1][14][12][48][23][10][9][37][24]$} & {$[30][8][13][32][56][35][5][27][41][40]$} \\
& {$[1][8][33][24][51]$} & {$[19][14][30][23][32][10][35][56][5]$} \\
Fysisk aktivitet & {$[30][10][32][40][24]$} & {$[37][40]$} \\
\hline
\end{tabular}

tivitet har for sykelighet og dødelighet har det nylig vært foreslått at fysisk inaktivitet isolert sett bør anses som en sykdom [58].

\section{EFFEKT AV FYSISK AKTIVITET}

Regelmessig fysisk aktivitet har en positiv innflytelse på blodtrykk [44], kolesterolnivå [54] og på hjerte- og karsystemet generelt [54]. Samtidig medfører økt aerob kapasitet (kondisjon) redusert dødelighet og sykelighet i den friske befolkning $[17,18,20]$ så vel som i høyprevalente sykdomsgrupper som representert ved hjertesvikt- [39,45] og KOLS-pasienter [16]. Nyere studier viser også at fysisk aktivitet reduserer risikoen for utvikling av en rekke tilstander og sykdommer som f.eks. metabolsk syndrom, brystkreft, tykktarmskreft, prostatakreft, kreft i bukspyttkjertelen, diabetes, høyt blodtrykk, astma, leddgikt, beinskjørhet og Alzheimer med 40-60\% [4]. Epidemiologiske studier har vist at individer med god kondisjon lever lenger enn personer med dårligere kondisjon, og antyder at selv små endringer $\mathrm{i}$ kondisjon kan gi betydelig økt forventet levealder $[25,36]$. I et helse- og samfunnsøkonomisk perspektiv er det også interessant at individer som har et bra kondisjonsnivå har opptil 15 flere leveår med god helse hvor de er selvhjulpne sammenliknet med de med dårlig kondisjonsnivå [49]. Når det gjelder hvilken type aktivitet og hvilke aktivitetsdoser som bør tilstrebes er fremdeles mye uavklart. Man kan vel med sikkerhet si at nærmest all form for fysisk aktivitet er helsefremmende og dermed å foretrekke fremfor inaktivitet. Resultater fra HUNT viser at selv én hard treningsøkt i uka var assosiert med 39\% redusert dødelighet for menn og $51 \%$ redusert dødelighet for kvinner [61]. Trening utover dette ga ingen ytterligere reduksjon i dødelighet, selv om andre studier der intensiteten er lavere viser en dose-respons sammenheng. Dette indikerer at man ved moderate tiltak kan oppnå store helsegevinster.

\section{TILTAK PÅ BEFOLKNINGSNIVÅ}

Tidlig på 1970-tallet ble det gjennomført flere store intervensjonsstudier med primærforebyggende hensikt, for eksempel Nord-Karelen prosjektet i Finland [47], CHAD-prosjektet i Israel [1] samt Stanford Three Community Project [14] og Franklin Community CVD Health Program I USA [48]. Studiene forsøkte å påvirke kostvaner, røykevaner og kroppsvekt samt risikofaktorer som hyperkolesterolemi og hypertensjon gjennom atferdsendringer i befolkningen, men resultatene har vært varierende. I løpet av de siste tiårene har det vært en tydelig global bedring i blodtrykk, kolesterolnivåer og utbredelsen av tobakkbruk, som igjen har redusert den totale kardiovaskulære risikobyrde [15]. De gode resultatene fra Nord-Karelen [47] har derfor blitt trukket $i$ tvil fordi påfølgende analyser viste at nedgangen i kardiovaskulær dødelighet var tilsvarende i Finland for øvrig [50]. På samme måte hadde flere av de store kardiovaskulære populasjonsintervensjonene $[8,13,30]$ problemer med å vise signifikante forskjeller sammenlignet med sekulære endringer i befolkningen forøvrig, selv om de isolert sett kunne vise til fordelaktige forandringer $\mathrm{i}$ de kardiovaskulære risikofaktorene.

Det er likevel holdepunkter for at populasjonsbaserte intervensjoner kan ha en gunstig effekt på risikofaktorer [14,23,24]. Tabell 1 oppsummerer populasjonsbaserte intervensjonsstudier og deres effekt på risikofaktorer og sentrale folkehelseparametere. Intervensjoner som har tatt sikte på å øke aktivitetsnivået $\mathrm{i}$ befolkningen har hatt vekslende hell. Selv om noen har lykkes i dette [10,24,30,32,40], har de fleste studier ikke kunnet vise til positive resultater [5,11,27,33,37, $41,56,62]$. Nøye planlagte forebyggingsprogrammer kan være et viktig tiltak for å øke aktivitetsnivået og redusere omfanget av kronisk sykdom, og McLaren et al [34] påpeker at man må identifisere de unike kontekstuelle trekkene ved målgruppen (sosiale, fysiske, økonomiske, politiske og kulturelle) for å oppnå suksess med en befolkningsintervensjon. Årsaken til at de negative resultatene $\mathrm{i}$ tidligere studier kan være at tiltakene ikke har vært tilstrekkelig dyptgripende og gjennomførbare. I tillegg har de fleste intervensjonsstudier fokusert på flere risikofaktorer, som røyking, kosthold og medikamentell behandling av høyt blodtrykk og høyt kolesterol, i tillegg til fysisk aktivitet. Med en så 


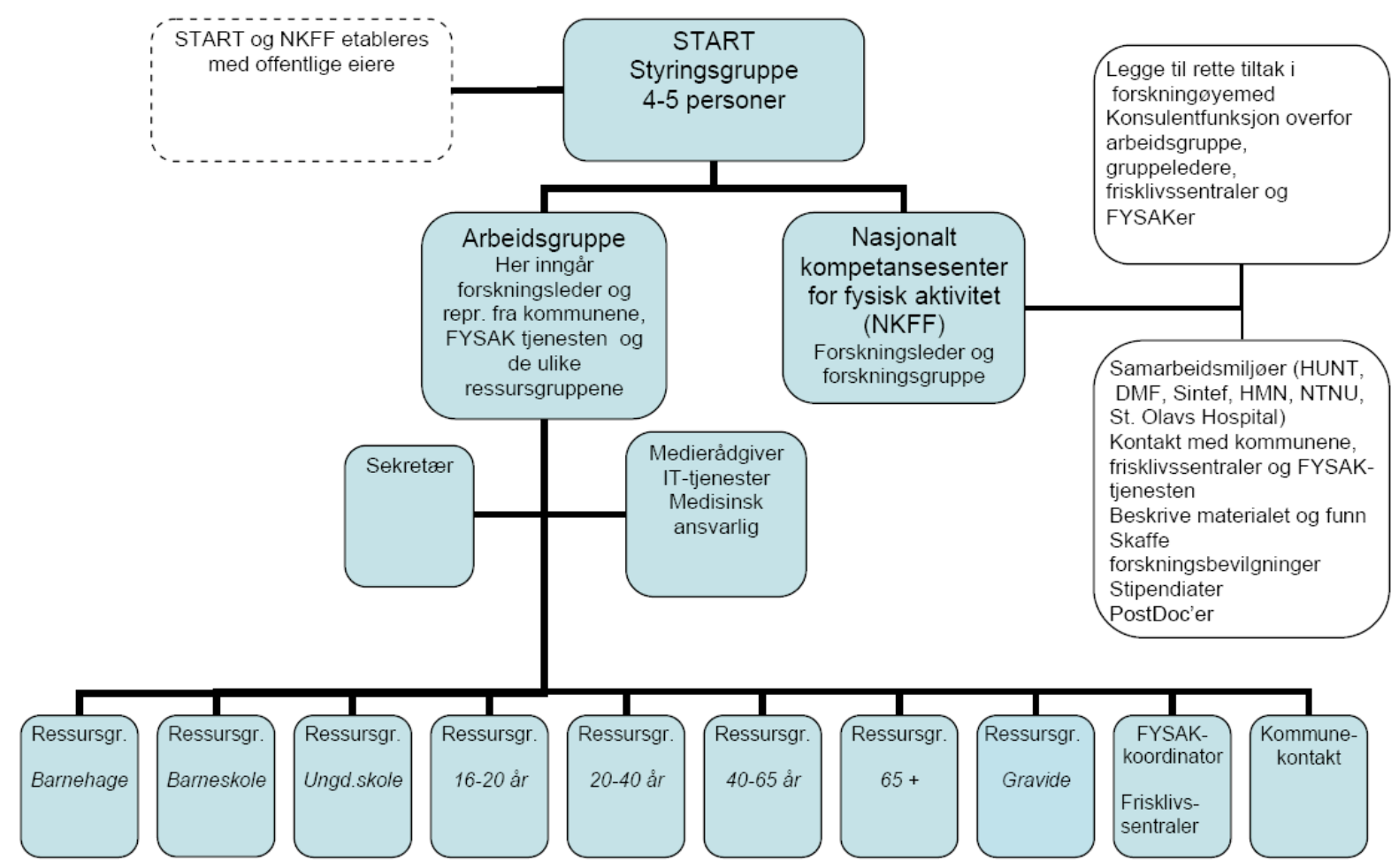

Figur 1. Foreløpig skisse over organiseringen av START. Ressursgruppene vil bestå av personer med særskilt kompetanse i forhold til den aktuelle populasjonen. Hver ressursgruppe utarbeider konkrete tiltakspakker som skal evalueres i arbeidsgruppa før implementering.

mangefasettert tilnærming vil det kunne være vanskelig å oppnå tilstrekkelig gode tiltak og nok fokus, for å oppnå den forventede effekten på fysisk aktivitet.

\section{START-PROSJEKTET}

Forebyggende tiltak i forkant av at lidelser oppstår, og spesielt intervensjoner fra ung alder av, vil ha et stort forebyggingspotensiale. Populasjonsbaserte strategier anses å være mer kostnadseffektive og bærekraftige enn individuelle intervensjoner [42]. En intervensjon med målsetning om å oppnå en samfunnsmessig helsegevinst bør derfor satse på moderat risikoreduksjon i hele befolkningen. En slik satsning må selvsagt ikke gå på bekostning av den behandling og oppfølging som tilbys de som allerede er syke eller i risikosonen. Det kan videre være hensiktsmessig også å spisse noen tiltak inn mot risikogrupper.

\section{MÅlsetting}

Målet med START er å oppnå bedret folkehelse og samfunnsøkonomisk gevinst ved å øke aktivitetsnivået i alle aldersgrupper i Sør-Trøndelag, og at dette vil danne grunnlag for implementering av tiltak på nasjonalt nivå. Gjennom økt fysisk aktivitet ønsker vi å redusere forekomsten av risikofaktorer som hypertensjon, glukoseintoleranse, hyperkolesterolemi og overvekt samt redusere insidensen av høyprevalente livsstilssykdommer som hjerte-/karsykdom, diabetes, kronisk obstruktiv lungesykdom og kreft. Videre er det et langsiktig mål å øke totaloverlevelsen i populasjonen, redusere sykefravær og antall uføretrygdede samt øke reell pensjonsalder slik at de totale helsekostnadene knyttet til livsstilssykdommer reduseres.

\section{DESIGN}

START er en koordinert populasjonsbasert dugnad for bedre helse med initiativ fra Institutt for sirkulasjon og bildediagnostikk ved det medisinske fakultet, NTNU. Prosjektet er i forprosjekteringsfasen, er bredt forankret i offentlige institusjoner og tverrfaglig basert (Tabell 2). Vi ønsker i størst mulig grad å benytte eksisterende samfunnsstrukturer som fastleger, helsevesen, NAV, skoler, SFO, barnehager, arbeidsliv, idrettslag og andre foreninger som utgangspunkt for tilrettelegging av økt aktivitetsnivå i Sør-Trøndelag. Dette krever et omfattende samarbeid mellom kommunale, fylkeskommunale, statlige og private instanser og organer, og vi ønsker å koordinere det hele gjennom START. Vi vil iverksette tiltak for å øke aktivitetsnivået $\mathrm{i}$ alle aldersgrupper, og vil etablere arbeidsgrupper som skal utarbeide konkrete tiltaksplaner for hver enkel subpopulasjon. Det er ønskelig med et moderat trykk i hele befolkningen der optimal tilrettelegging for de ulike subpopulasjonene, familietilpassede tiltak og positivitet er sentrale stikkord for å øke aktivitetsnivået. Figur 1 illustrerer START-organisasjonen slik vi ønsker å etablere den. Tidligere populasjonsbaserte interven- 
sjonsstudier som har tatt mål av seg å øke aktivitetsnivået i befolkningen (Tabell 1) har bestått av en kombinert satsing på kosthold, fysisk aktivitet, tobakkbruk og medikamentell behandling av hypertensjon og hyperlipidemi/kolesterolemi. De moderate, og tidvis fraværende effektene av disse studiene kan skyldes at man forsøker å gjøre for mye med for mange, og at fokuset på fysisk aktivitet har vært for lite. Vi mener derfor at man ved å ha ett enkelt fokus, nemlig økt fysisk aktivitet, vil ha større mulighet for å lykkes. Når det gjelder konkrete tiltak for best å nå ut til de ulike målgruppene, vil dette blir utformet av ressursgruppene (Figur 1). Tidlig intervensjon har det største potensialet, og vi vil således fokusere sterkt på tiltak $i$ barne- og ungdomsårene. Her vil skoler, SFO, barnehager og idrettslag spille en sentral rolle. Både når det gjelder barn og voksne vil det være avgjørende for suksess at tiltakene treffer de som allerede er inaktive. Dette vil være en særlig utfordring. Bruk av samfunnsstrukturene beskrevet ovenfor kombinert med tilpassede anbefalinger som oppleves som overkommelige for den enkelte og med muligheter for oppfølging vil være viktig.

\section{NASJONALT KOMPETANSESENTER FOR FYSISK AKTIVITET (NKFF)}

En sentral del av START vil være etableringen av NKFF som skal være et teoretisk og praktisk kompetansesenter for fysisk aktivitetsmedisin og således ivareta den faglige plattformen i START-prosjektet. Målsettingen er at senteret skal jobbe tett med lokale, regionale og nasjonale helsemyndigheter og politiske myndigheter, samt lokale og regionale idrettsforeninger/foreninger. NKFF skal også jobbe aktivt med de nyetablerte Frisklivssentralene ute i kommunene. Forskning og dokumentasjon vil være sentrale oppgaver i samarbeid med Helsedirektoratet, Helse MidtNorge, HUNT, St. Olavs Hospital og NTNU. NKFF vil også arbeide med behandling av utsatte grupper i samfunnet etter henvisning fra fastleger, helsesøstre, sykehusleger, HMS-tjenester, fysioterapeut og NAV i form av individuell og gruppebasert oppfølging.

\section{FORSKNING}

Det vil være viktig å kunne vurdere effekten av de ulike tiltakene, og på sikt justere, fjerne eller innføre tiltak. En slik evaluering krever inngående kunnskap om forskning og prosjektarbeid. I tillegg til resultater på kort sikt som kan rettelede myndighetene i valg av tiltak på nasjonalt nivå, ønsker vi også å videreføre START-prosjektet i flere tiår fremover da det er i et slikt tidsperspektiv en virkelig vil kunne se den fulle effekten av primærforebyggende tiltak fra ung alder. Resultatene i START kan kontrolleres mot en annen populasjon (som for eksempel Nord-Trøndelag og HUNT), mot seg selv, eller på grunnlag av ukon- trollerte endringer vurdert opp mot tidligere studier. Man kan vurdere den undersøkte populasjonen opp mot den generelle utviklingen i mortalitet og sykdomsforekomst i landet eller annet fylke, eller tidligere tendenser i samme populasjon. Kreftregisteret, infarktregisteret og dødsårsaksregisteret kan brukes til slike sammenligninger.

\section{FREMDRIFTSPLAN}

Et prosjekt som dette krever grundig forprosjektering, og tiden fram til 2013 vil gå med til planlegging, etablering og finansieringsarbeid (Tabell 3). Fra 2014 vil START tiltak iverksettes i full skala mot alle subpopulasjoner.

Tabell 2. START - initiativtagere og støttespillere.

Institutt for sirkulasjon og bildediagnostikk, NTNU Institutt for samfunnsmedisin, NTNU

Program for lærerutdanning, NTNU

Institutt for sosiologi og statsvitenskap, NTNU

Program for bevegelsesvitenskap, NTNU

Institutt for nevromedisin, NTNU

NTNU Samfunnsforskning AS, Senter for idrettsforskning

Høyskolen i Sør-Trøndelag, Avdeling for lærer- og tolkeutdanning

Dronning Mauds Minne, Seksjon for fysisk fostring

Sør-Trøndelag Idrettskrets

Fylkesmannen i Sør-Trøndelag

Sør-Trøndelag Fylkeskommune

Trondheimregionens friluftsråd

Den Norske Kreftforening

Nasjonalforeningen for folkehelsen

Helsedirektoratet

Tabell 3. START - fremdriftsplan.

Fase 1: 2010 Planleggingsfase:

- Intern og ekstern idéfase (rådgivning, gradvis spissing av prosjekt)

- Etablere prosjektbeskrivelse

- Etablere styringsgruppe, rådgivingsgruppe og ressursgrupper

- Innhente midler til opprettelsen av Nasjonalt senter for fysisk aktivitet

Fase 2: 2011-2013 Etablerings- og finansieringsfase:

- Etablere Nasjonalt senter for fysisk aktivitet

- Innarbeide prosjektfinansiering for START gjennom Statsbudsjettet

- Prosjektdesign av START (forskning, satsningsområder, omfang)

- Utarbeide en forskningsplan og kommunikasjonsplan

- Etablere samarbeidsavtaler: Helse Midt-Norge, NTNU, SørTrøndelag fylkeskommune, lokalkommuner, frisklivssentraler, idrettslag, kommunale fysisk-aktivitets-koordinatorer m.fl.

- Gradvis implementering av tiltak

Fase 3: 2014- Igangsetting START:

- Iverksette START-tiltak for fullt i Sør-Trøndelag. 


\section{REFERANSER}

1. Abramson JH, Gofin R, Hopp C, et al. Evaluation of a community program for the control of cardiovascular risk factors: the CHAD program in Jerusalem. Isr J Med Sci 1981; 17: 201-12.

2. Albright A, Franz M, Hornsby G, et al. American College of Sports Medicine position stand. Exercise and type 2 diabetes. Med Sci Sports Exerc 2000; 32: 1345-60.

3. Anderssen SA, Carroll S, Urdal P, et al. Combined diet and exercise intervention reverses the metabolic syndrome in middle-aged males: results from the Oslo Diet and Exercise Study. Scand J Med Sci Sports 2007; 17: 687-95.

4. Booth FW, Chakravarthy MV, Gordon SE, et al. Waging war on physical inactivity: using modern molecular ammunition against an ancient enemy. $J$ Appl Physiol 2002; 93: 3-30.

5. Brownson RC, Smith CA, Pratt M, et al. Preventing cardiovascular disease through community-based risk reduction: the Bootheel Heart Health Project. Am J Public Health 1996; 86: 206-13.

6. Bull FC, Gauvin L, Bauman A, et al. The Toronto Charter for Physical Activity: a global call for action. $J$ Phys Act Health 2010; 7: 421-2.

7. Byberg L, Melhus H, Gedeborg R, et al. Total mortality after changes in leisure time physical activity in 50 year old men: 35 year follow-up of population based cohort. Br J Sports Med 2009; 43: 482.

8. Carleton RA, Lasater TM, Assaf AR, et al. The Pawtucket Heart Health Program: community changes in cardiovascular risk factors and projected disease risk. Am J Public Health 1995; 85: 777-85.

9. Chen $\mathrm{J}, \mathrm{Wu} \mathrm{X}, \mathrm{Gu} \mathrm{D}$. Hypertension and cardiovascular diseases intervention in the capital steel and iron company and Beijing Fangshan community. Obes Rev 2008; 9: 142-5.

10. Dowse GK, Gareeboo H, Alberti KG, et al. Changes in population cholesterol concentrations and other cardiovascular risk factor levels after five years of the non-communicable disease intervention programme in Mauritius. Mauritius Non-communicable Disease Study Group. BMJ 1995; 311: 1255-9.

11. Eaton CB, Lapane KL, Garber CE, et al. Effects of a community-based intervention on physical activity: the Pawtucket Heart Health Program. Am J Public Health 1999; 89: 1744.

12. Egger G, Fitzgerald W, Frape G, et al. Results of large scale media antismoking campaign in Australia: North Coast "Quit for Life" programme. BMJ 1983; 287: 1125-8.

13. Farquhar JW, Fortmann SP, Flora JA, et al. Effects of communitywide education on cardiovascular disease risk factors. The Stanford Five-City Project. JAMA 1990; 264: 359-65.

14. Farquhar JW, Maccoby N, Wood PD, et al. Community education for cardiovascular health. Lancet 1977; 1: $1192-5$.

15. Ford ES, Ajani UA, Croft JB, et al. Explaining the decrease in U.S. deaths from coronary disease, 1980-2000. $N$ Engl J Med 2007; 356: 2388-98.

16. Garcia-Aymerich J, Lange P, Serra I, et al. Time-dependent confounding in the study of the effects of regular physical activity in chronic obstructive pulmonary disease: an application of the marginal structural model. Ann Epidemiol 2008; 18: 775-83.

17. Gregg EW, Cauley JA, Stone K, et al. Relationship of changes in physical activity and mortality among older women. JAMA 2003; 289: 2379-86.

18. Gulati M, Pandey DK, Arnsdorf MF, et al. Exercise capacity and the risk of death in women: the St James Women Take Heart Project. Circulation 2003; 108: 1554-9.

19. Gutzwiller F, Nater B, Martin J. Community-based primary prevention of cardiovascular disease in Switzerland: methods and results of the National Research Program (NRP 1A). Prev Med 1985; 14: 482-91.

20. Hakim AA, Petrovitch H, Burchfiel CM, et al. Effects of walking on mortality among nonsmoking retired men. N Engl J Med 1998; 338: 94-9.

21. Helse- og Omsorgsdept. St.meld.nr.47, Samhandlingsreformen. 2009.

22. Helsedirektoratet. Nøkkeltall for helsesektoren 2009. 2009.

23. Hoffmeister H, Mensink GB, Stolzenberg H, et al. Reduction of coronary heart disease risk factors in the German cardiovascular prevention study. Prev Med 1996; 25: 135-45.

24. Jenum AK, Anderssen SA, Birkeland KI, et al. Promoting physical activity in a low-income multiethnic district: effects of a community intervention study to reduce risk factors for type 2 diabetes and cardiovascular disease: a community intervention reducing inactivity. Diabetes Care 2006; 29: 1605-12.

25. Kavanagh T, Mertens DJ, Hamm LF, et al. Prediction of long-term prognosis in 12169 men referred for cardiac rehabilitation. Circulation 2002; 106: 666-71.

26. Khavjou OA, Finkelstein EA, Will JC. The impact of medication use in a multicomponent intervention: results from the WISEWOMAN program. Am J Health Promot 2007; 21: 267-73.

27. Kloek GC, van Lenthe FJ, van Nierop PW, et al. Impact evaluation of a Dutch community intervention to improve health-related behaviour in deprived neighbourhoods. Health Place 2006; 12: 665-77. 
28. Knowler WC, Barrett-Connor E, Fowler SE, et al. Reduction in the incidence of type 2 diabetes with lifestyle intervention or metformin. N Engl J Med 2002; 246: 393-403.

29. Lindstrom J, Ilanne-Parikka P, Peltonen M, et al. Sustained reduction in the incidence of type 2 diabetes by lifestyle intervention: follow-up of the Finnish Diabetes Prevention Study. Lancet 2006; 368: 1673-9.

30. Luepker RV, Murray DM, Jacobs DR, Jr., et al. Community education for cardiovascular disease prevention: risk factor changes in the Minnesota Heart Health Program. Am J Public Health 1994; 84: 1383-93.

31. Luepker RV, Rastam L, Hannan PJ, et al. Community education for cardiovascular disease prevention. Morbidity and mortality results from the Minnesota Heart Health Program. Am J Epidemiol 1996; 144: 351-62.

32. Lupton BS, Fønnebø V, Søgaard AJ, et al. The Finnmark Intervention Study: is it possible to change CVD risk factors by community-based intervention in an Arctic village in crisis? Scand J Public Health 2003; 31: $178-86$.

33. Lupton BS, Fønnebø V, Søgaard AJ, et al. The Finnmark Intervention Study. Better health for the fishery population in an Arctic village in North Norway. Scand J Prim Health Care 2002; 20: 213-8.

34. McLaren L, Ghali LM, Lorenzetti D, et al. Out of context? Translating evidence from the North Karelia project over place and time. Health Educ Res 2007; 22: 414-24.

35. Muntoni S, Stabilini L, Stabilini M, et al. Results of a five-year community-based programme for cardiovascular disease prevention: the ATS-Sardegna Campaign. Eur J Epidemiol 1999; 15: 29-34.

36. Myers J, Prakash M, Froelicher V, et al. Exercise capacity and mortality among men referred for exercise testing. N Engl J Med 2002; 346: 793-801.

37. Nafziger AN, Erb TA, Jenkins PL, et al. The Otsego-Schoharie healthy heart program: prevention of cardiovascular disease in the rural US. Scand J Public Health 2001; Suppl 56: 32.

38. Nasjonalt folkehelseinstitutt for Helsedepartementet. Folkehelserapporten 2002. 2002.

39. O'Connor CM, Whellan DJ, Lee KL, et al. Efficacy and safety of exercise training in patients with chronic heart failure: HF-ACTION randomized controlled trial. JAMA 2009; 301: 1439-50.

40. O'Loughlin JL, Paradis G, Gray-Donald K, et al. The impact of a community-based heart disease prevention program in a low-income, inner-city neighborhood. Am J Public Health 1999; 89: 1819-26.

41. Osler M, Jespersen NB. The effect of a community-based cardiovascular disease prevention project in a Danish municipality. Dan Med Bull 1993; 40: 485-9.

42. Papadakis S, Moroz I. Population-level interventions for coronary heart disease prevention: what have we learned since the North Karelia project? Curr Opin Cardiol 2008; 23: 452-61.

43. Parrott S, Godfrey C. Economics of smoking cessation. BMJ 2004; 328: 947-9.

44. Pescatello LS, Franklin BA, Fagard R, et al. American College of Sports Medicine position stand. Exercise and hypertension. Med Sci Sports Exerc 2004; 36: 533-53.

45. Piepoli MF, Davos C, Francis DP, et al. Exercise training meta-analysis of trials in patients with chronic heart failure (ExTraMATCH). BMJ 2004; 328: 189.

46. Puska P. Fat and heart disease: yes we can make a change - the case of North Karelia (Finland). Ann Nutr Metab 2009; 54: 33-8.

47. Puska P, Salonen JT, Nissinen A, et al. Change in risk factors for coronary heart disease during 10 years of a community intervention programme (North Karelia project). BMJ 1983; 287: 1840-4.

48. Record NB, Harris DE, Record SS, et al. Mortality impact of an integrated community cardiovascular health program. Am J Prev Med 2000; 19: 30-8.

49. Redberg RF, Greenland P, Fuster V, et al. Prevention Conference VI: Diabetes and Cardiovascular Disease: Writing Group III: risk assessment in persons with diabetes. Circulation 2002; 105: 144-52.

50. Salonen JT. Did the North Karelia project reduce coronary mortality? Lancet 1987; 2: 269.

51. Schuit AJ, Wendel-Vos GCW, Verschuren WMM, et al. Effect of 5-Year Community Intervention Hartslag Limburg on Cardiovascular Risk Factors. Am J Prev Med 2006; 30: 237-42.

52. Stene LC, Midthjell K, Jenum AK, et al. Prevalence of diabetes mellitus in Norway. Tidsskr Nor Laegeforen 2004; 124: 1511-4.

53. The NHS Information Centre LU. Health Survey for England - 2008: Physical activity and fitness. 2009.

54. Thompson PD, Buchner D, Pina IL, et al. Exercise and physical activity in the prevention and treatment of atherosclerotic cardiovascular disease: a statement from the Council on Clinical Cardiology (Subcommittee on Exercise, Rehabilitation, and Prevention) and the Council on Nutrition, Physical Activity, and Metabolism (Subcommittee on Physical Activity). Circulation 2003; 107: 3109-16.

55. Troiano RP, Berrigan D, Dodd KW, et al. Physical activity in the United States measured by accelerometer. Med Sci Sports Exerc 2008; 40: 181-8.

56. Tudor-Smith C, Nutbeam D, Moore L, et al. Effects of the Heartbeat Wales programme over five years on behavioural risks for cardiovascular disease: quasi-experimental comparison of results from Wales and a matched reference area. BMJ 1998; 316: 818-22.

57. Universitetet i Bergen. HEMIL-rapport 3/2009. 2009.

58. Weiler R, Stamatakis E. Physical activity in the UK: a unique crossroad? Br J Sports Med 2010; 44: 912-4. 
59. Weinehall L, Hellsten G, Boman K, et al. Can a sustainable community intervention reduce the health gap? 10-year evaluation of a Swedish community intervention program for the prevention of cardiovascular disease. Scand J Public Health 2001; Suppl 56: 68.

60. WHO.The World Health Organisation. The world health report 2002 - Reducing Risks, Promoting Healthy Life. 2002.

61. Wisløff U, Nilsen TIL, Drøyvold WB, et al. A single weekly bout of exercise may reduce cardiovascular mortality: how little pain for cardiac gain? 'The HUNT study, Norway'. Eur J Cardiovasc Prev Rehabil 2006; 13: 798-804.

62. Young DR, Haskell WL, Jatulis DE, et al. Associations between changes in physical activity and risk factors for coronary heart disease in a community-based sample of men and women: the Stanford Five-City Project. Am J Epidemiol 1993; 138: 205-16. 